6. Шарманова, Н. М. (2015). Етнолінгвістика : навчальний посібник для студентів факультету української філології. Кривий Ріг : НПП АСТЕРІКС, 2015. $192 \mathrm{c}$.

7. Lopatynska N.A. Linguistic and communicative competence in university students as a component of future correction teacher. Actual problems of the correctional education: Ministry of Education and Science of Ukraine, National Pedagogical Drahomanov University, Kamyanets-Podilsky Ivan Ohyenko National University. Kamyanets-Podilsky: Medobory2006, 2015.- P. 187-197. URL: https://aqce.com.ua/download/publications/ 203/239.pdf/

DOI https://doi.org/10.30525/978-9934-26-110-7-56

\title{
ІНТЕРПРЕТАЦІЯ МОВНИХ ФОРМУЛ НА ЕТНОКУЛЬТУРНОМУ ТЛІ
}

\author{
Філіпчук М. В. \\ кандидат філологічних наук, \\ доцент кафедри історії та культури украӥнської мови \\ Чернівецький національний університет імені Юрія Федьковича \\ Попович Н. М. \\ кандидат філологічних наук, \\ доиент кафедри історії та культури украӥнської мови \\ Чернівецький національний університет імені Юрія Федьковича \\ м. Чернівиі, Україна
}

Життєдайною силою, невичерпним джерелом мудрості народу є народна мова, народне слово, яке $\epsilon$ засобом пізнання навколишнього світу, історії свого народу, його вірувань та обрядів. Саме у слові, за О. Потебнею, виражається реальна думка, а «сила людської думки не в тому, що слово викликає в свідомості попередні сприйняття, а в тому, як саме воно примушує людину користуватися скарбами свого минулого» [4, с. 143]. Впродовж століття у народній мовній свідомості переосмислюється світ реалій, у результаті чого формується категоризація на модель зовнішнього світу.

Активізація дослідження мовних явищ у світі суміжних галузей знань породили нові наукові напрямки, зокрема й етнолінгвістику. Основу етнолінгвістичних досліджень заклали у своїх працях ще В.фон Гум- 
больдт, Д. Зеленін, І. Огієнко, О. Потебня, Е. Сепір та ін., які використовували не лише дані мовознавства, а й етнографії, зокрема й контексти народної культури. У другій половині ХХ ст. значний внесок у розвиток етнолінгвістики зробили Є. Верещагін, В. Костомаров, А. Вежбицька, С. Срмоленко, В. Жайворонок, В. Русанівський, О. Тищенко та ін. Сучасні дослідження мовних одиниць грунтуються здебільшого на широкому залученні позамовних чинників, пов'язаних з широкими культурними надбаннями народу.

У центрі лінгвістичних досліджень співвідношення понять мова культура - етнос постає у нових аспектах. Народні уявлення про довкілля, а також система відносин між людьми певною мірою відбилися й у фразеологічних одиницях як мовних корелятивах духовної культури етносу. Від власне фразеологізмів вони відрізняються тим, що їхні компоненти зберігають своє пряме лексичне значення і їм не властиве емоційно-експресивне забарвлення. Тобто у народному мовленні виділяємо своєрідне кліше. Кліше - це звичний зворот, регулярно повторюваний у певних умовах і контекстах для тотожного позначення адекватних ситуацій, стосунків між людьми. Так, у народних обрядодіях спостерігаємо клішовані структури мовного етикету: 3 роси $i$ води; Бажаємо щастя й добра; На все добре; Ласкаво просимо; Дай, Боже, з роси, з води!; Дай, Боже, разом двоє: щастя та здоров'я!; Дай, Боже, щоб пилось і їлось та й назавтра хотілось!; Дай, Боже, (Нехай Бог дає) щзастя, здоров'я На многія літа всім!; Нехай тобі, дитино, прибавить в ручки, ніжки і в животик трішки!; Боже вас благослови і материними, і батьковими молитвами!; Хай тобі Бог дає вік щасливий та довгий!; Нехай вам буде кожна година щчаслива!; Хай вам Бог пошле, чого в нього просите!; Хай вас Бог подержить на сім світі!; Дай, Боже, щоб ти сину, говорив, як по зорях читав!; Бувай здорова од припічка до порога!; Щоб ти була багата, як земля, дужа, як вода, щоб у коморі і в оборі усього було доволі! Як бачимо, такі настановчі мовні одиниці передають або побажання, або виступають ритуальною вітальною формулою при зустрічі чи прощанні («до слова сказати»). Вони сприймаються як певний набір перифраз, що свідчить про етнокультурний зміст мовних одиниць, які сформувалися протягом тривалого часу.

В обрядових контекстах, надибуємо також на численні сталі вирази зі спонукальною часткою щоб, що характерно власне для обрядового мовлення, напр.: щеоб иі свята відпровадити та других дочекати; щоб на той рік дождати сон-траву топтати (формула примовка, коли топчуть ряст чи сон-траву навесні, сподіваючись дочекатися наступного року у здоров’ї); щоб була здорова, як вода, а багата, як земля; щьоб робилось 
та не псувалось; щуоб заснуло лихо і між нами було тихо; щуоб нам жито родило, і житечко, і овес, щуоб збирався рід наш увесь; щуоб старі вороги рачки лазили, а молодим, щчоб очі вилазили; щчоб вам онуків діждати; щуоб нам ще сто літ зустрічатися та ін.

Разом 3 тим є ряд фразеологізованих сполук реченнєвого типу, що становлять собою прислів'я та приказки. Саме вони здатні часом схарактеризувати і виразно, стисло передати будь-що без ускладнених пояснень, при цьому наповнюючись поетичною образністю, напр.: живе як у Бога за дверима (за кроснами, за пазухою, за плечима, під покриикою) - дуже добре; зложив сі як Божечка - про святошу, що вдає із себе праведника; не минеться як бабі Великдень - без шкоди.

Словесна формула прислів'я $є$ його зовнішньою формою, а внутрішня форма - це глибинне поняття, яке часто сягає глибини віків. Напр.: $H a$ все свій час і година своя кожній справі під небом; Не хлібом самим буде жити людина, але кожним словом, щуо виходить із уст Божих; Хоч з моста та в воду; Проти сили не попреш, з чим родився, з тим і вмреш; Доки сонце зійде, роса очі виїсть. Здебільшого паремії побудовані на протиставленні, пор.: Чужих богів шукає, а своїх дома має; Іти з Богом, іти до чорта; Дай, Боже, ноги, а чорт колеса; Ні Богові свічка, ні чортові ладан; Як не тепер, так у четвер; Ні туди, ні сюди.

Для етносимволіки неабияке значення мають причинові відношення, які виникають у середині сталих виразів порівнянь на основі ототожнення певних якостей: гарна, як сонще; гарна, хоч з личка воду пити; гарна, наче рожа; гарна дівка, як маківка; дівка рум'яна, як ружа; дівка, як рожа, бий ї̈ сила Божа; гірке його життя, як полин; живуть, як віночки плетуть; багатий як земля; глянула і мов сонце ясне засвітилось або кажуть: Чи в любистку ти купався, щзо мені сподобався? Саме на основі порівняння в народному мовленні постали мовні вирази, у яких домінантою виступає прикметник, напр.: Весела як весна; Весела як ясочка; Гарна наче рожа; Високий як смерека; Кремезний наче дуб; Прямий як смерека; Злий як чорт; Ласкава наче сонце; Сердита як відьма; Сердита як кропива. Для цих форм характерна також метафоричність, що виникає на основі образного мислення з елементами порівняння, напр.: Дівка, як верба, де посади - там прийметься; Хлопецьь молодий, як барвінок в'юнкий; Хлопецьь моторний, як живе срібло проворний. Як бачимо, обов'язковим чинником у побудові компаративного змісту таких стійких народних порівнянь $є$ наявність порівняльних сполучників наче, як, ніби, що сприяє підкресленню певної метафоричності. Вживання стійких народних порівнянь, приказок, прислів'їв допомагає іноді знизити певну категоричність у висловлюванні, напр.: 
від вогню, води і лихої жінки сохрани мене Господи; потрібен як старій бабі вінок на голову; зажурилась як у воду опущена; сидить як у Бога за дверима; зійде як вода; пропав як камінь у воду упав; Бог дасть долю і в чистім полю.

Отже, слово у мові виконує універсальну функцію, адже через нього усвідомлюємо не тільки певні поняття, а й створюємо власні образи на основі порівняння, метафоричності, паралелізму. При цьому символікою позначене не лише слово (вираз) як таке, а його форма теж.

\section{Література:}

1. Денисенко С., Хлівний В. Національно-культурна своєрідність фразеологізмів з погляду взаємозв'язку мови і культури. Язык и культура: Докл. второй Международной конференции. К., 1993. С. 96-99.

2. Жайворонок В. Міфологія і мовний світ народу в інтерпретації О. О. Потебні. Наукова спадщина О. О. Потебні в контексті сучасності. IV Міжнародний конгрес україністів. Одеса, 26-29 серпня 1999 р. К., 2002. С. 780-785.

3. Жайворонок В. Національна мова та ідіолект. Мовознавство. 1998. № 6. С. 27-34.

4. Потебня А. Мысль и язык. Эстетика и поэтика. М.: Искуство, $1976.614 \mathrm{c}$.

5. Філіпчук М.В. Символіка фразеологічних одиниць в етнокультурному контексті. Проблеми гуманітарних наук. Серія: Філологія. 2016. C. 274-281.

6. Фразеологічний словник української мови: У 2 кн. / Уклад. В.М. Білоноженко, В.О. Винник, І.С. Гнатюк та ін. К.: Наук. думка, 1993. 